\title{
AN OVERVIEW OF AMPHIBIAN FAUNA OF MAHARASHTRA STATE
}

\author{
A.D. Padhye ${ }^{1}$ and H.V. Ghate ${ }^{2}$ \\ ${ }^{1}$ Department of Zoology, Abasaheb Garware College, Pune, Maharashtra 411004, India. \\ ${ }^{2}$ Department of Zoology, Modern College, Shivajinagar, Pune, Maharashtra 411005, India. \\ Emails: ${ }^{1}$ nandudp@yahoo.com; ${ }^{2}$ hemantghate@hotmail.com
}

\begin{abstract}
There are 43 species of amphibia in Maharashtra State of the 224 species found in India, distributed among six different families as: Icthyophiidae, Caecilidae, Bufonidae, Microhylidae, Ranidae and Rhacophoridae. Out of seven genera endemic to the Western Ghats, three are represented in Maharashtra State.
\end{abstract}

\section{Keywords}

Amphibians, Maharashtra State, overview,

\section{Introduction}

Maharashtra State $\left(15^{\circ}-22^{\circ} \mathrm{N}\right.$ and $\left.72^{\circ}-81^{\circ} \mathrm{E}\right)$ is in the northwestern part of peninsular India. The northern parts of Western Ghats are present on the western margin of the state around 60 to $70 \mathrm{~km}$ from the Arabian Sea coast. The Ghats extend east as well as west, at some places even up to the seashore. There is a peculiar geographical feature called Konkan Kada, which is a formation of a series of cliffs of height 200-300m (minimum) that extends almost throughout the length of Western Ghats in Maharashtra. Due to the Konkan Kada, Western Ghats form a hurdle in the way of southwestern monsoon clouds thereby receiving a very high rainfall (average ca. $6,000 \mathrm{~mm}$ ); some places like Mahabaleshwar and Bhimashankar receiving up to $10,000 \mathrm{~mm}$. The western districts of Kolhapur, Sindhudurga, Satara, Ratnagiri, Pune, Raigad, Nasik and Thane are rich in biodiversity as they harbour parts of the Western Ghats.

Western Ghats is one of the world's 25 biodiversity hotspots (Myers, 2000) with many species of plants and animals endemic to the region. The detailed biogeography of this region has been attempted earlier by several scientists in a book edited by M.S. Mani (1974). Recently even Myers (2000) has compiled recent information about Western Ghats. There are 117 species of amphibians in the Western Ghats, which fall in 21 genera, six families and two orders (Daniels, 1992a).
The middle as well as eastern parts of the State are, however, dry as compared to western Maharashtra. These parts are semiarid or arid with extreme climate. This constitutes a part of the Deccan Plateau and possesses mainly dry deciduous forests or scrubland.

The northern boundary of the State has forests in the Satpura Mountain ranges as those found in Kanha National Park and Melghat Sanctuary. Since the eastern most region of the State is nearer to the Bay of Bengal it is influenced by both onward and return monsoon. It shows some large forests at Tadoba National Park as well as in the Nagzira and Navegaon sanctuaries.

Since Boulenger's fauna volume on reptiles and amphibians of the then British India (Boulenger, 1890), there is no single monograph dealing with all Indian amphibian species. Inger and Dutta published an overview of the amphibian fauna of India in 1986. In 1992 Dutta published a species list of amphibians of India with distribution record. Dutta (1997) subsequently published an updated checklist of amphibians of India and Sri Lanka.

The first list of amphibians of Maharashtra State, which included 22 species, was prepared by Daniel for the Maharashtra State Gazetteer (Daniel, 1974). Prior to that and subsequently, Daniel published a series of papers dealing with the amphibians of western India (Daniel, 1963, 1975; Daniel \& Sekar, 1989) and also commented on the distribution. Ravichandran and Pillai (1990) published a list of amphibians of Maharashtra. This paper is based on the examination of 223 amphibian specimens collected by the Western Regional Station of the Zoological Survey of India. The collection belonged to 13 species, of which one Ansonia kamblei was described as a new species. However, on the basis of known morphometry of juveniles of Bufo melanostictus, Dubois and Ohler (1999) have suggested that Ansonia kamblei should be treated as a synonym of Bufo melanostictus although they have not examined the holotype. Thus the assessment of the total faunistic wealth of amphibia of 
Maharashtra should await a detailed study on the basis of additional surveys.

According to Dutta (1997), there are only 24 species of amphibians known from Maharashtra. Two Bufonid members (Bufo microtympanum and B. parietalis), which were recorded from Pune (Maharashtra) by Yazdani and Mahabal (1976), are not mentioned in Dutta's list. The list of amphibians of Maharashtra, published by Ravichandran and Pillai (1990), was also apparently not considered during this updating (most probably because the paper was actually published very late). This kind of distributional omission in an overview of the amphibian fauna of India, published by Inger and Dutta (1986), has been pointed out earlier by Sekar (1991).

The most recent publication on the amphibians of Maharashtra is by A.G. Sekar (1999). He reported four species for the first time from Maharashtra. With these additions, he compiles the list of amphibians from the State as 34. Even this list is incomplete, as he has not included a Rhacophorid, which was included as Rhacophorus leucomystax (Kuhl) by Ravichandran and Pillai (1990).

The present work is compilation of the previous information regarding the amphibian fauna of Maharashtra State in addition to our own surveys in various localities. It should be mentioned here that we have not conducted any deliberate, intensive survey of the entire State due to lack of both funds as well as trained manpower. Moreover, most of our survey localities are in the western part of the State in the Western Ghats region.

\section{Observations and Discussion}

\section{Status of amphibians in Maharashtra State}

Amphibians from Pune and nearby areas like Kas, Thoseghar, Mahableshwar, Kolhapur, Satara, Koyna, etc., from other neighbouring districts of Maharashtra State were also studied. Sporadic collections from distant places like Tadoba, Amboli, Harihareshwar, Alibag, Phansad, etc. were also studied. Our updated list (Table 1) shows 43 species of amphibia from Maharashtra, but we could not obtain all the species. We have so far observed only 31 species collected from different areas of Maharashtra State, by our colleagues, friends and our team (marked with*). During our surveys we observed nine of these species, which are new locality records (marked with $* *$ ), that were not present in Selar's list (Sekar, 1999).

These 43 species of amphibia are distributed among six different families, namely, Icthyophiidae, Caecilidae, Bufonidae, Microhylidae, Ranidae and Rhacophoridae. Table 2 shows the distribution of these 43 species within six different families. It also shows comparative status of family-wise distribution of amphibian species among 10 families in India, Western Ghats and Maharashtra State.
Out of 10 families from India, six (60\%) are represented in Maharashtra State. Family Ranidae seems to predominate over the other families. Out of 224 Indian amphibian species only 19\% (43 species) are known from the State.

There are seven genera, e.g., Indotyphlus, Uraeotyphlus, Gegeneophis, Nyctibatrachus, Melanobatrachus, Micrixalus and Indirana, which are endemic to Western Ghats (Molur \& Walker, 1998). Three of these seven genera are represented in Maharashtra State, viz., Nyctibatrachus, Indotyphlus and Indirana.

So far as the status of these species is concerned, it is difficult to make any concrete statements as hard data are wanting. Reliable population data from monitoring is not available in India for most amphibians. Keeping in view our inability to give any quantitative information and hence true status, we present information only on the basis of qualitative data.

As far as the members of Gymnophiona are concerned the situation is worst. We are not aware if any one has observed or collected Ichthyophis subterrestris from the locality from where it was once collected, at least in the last 25 years or so. Indotyphlus battersbyi, which is originally described from Lonawla - Khandala, has not been observed there (to our knowledge) for many years. However, recently a specimen was collected from Supegaon (Bhat, 1997). With the exception of a few species of Ichthyophis, most Gymnophiona should be considered threatened, however, extensive surveys may reveal their exact status. Only a handful of biologists are working on this group of interesting animals and biology of most of the species is not known. Bhat (1997) published a checklist of Gymnophiona of Western Ghats and recently Ravichandran and Pillai (1999) published the Fauna of Gymnophiona of India.

Species of Bufonidae, overall, seem to be doing well. Bufo melanostictus is very common while B. stomaticus is perhaps the next common member. B. stomaticus was collected from only one locality (Chakan) near Pune and should be protected as this locality is changing due to industrialisation. $B$. koynayensis is found only in restricted localities nearby typelocality and should be protected. Nothing can be said with certainty about $B$. beddomii, $B$. parietalis and $B$. microtympanum; we have not personally observed any one of these species near Pune. These are relatively small and cryptic forms and are perhaps present as small populations in restricted areas.

Of the microhylid frogs perhaps the most common and widely distributed species is Microhyla ornata (found all over the State), while M. rubra is so far known only from a single locality - Wasumbe Tank, Wita, District Sangli (Ravichandran \& Pillai, 1990; Kamble \& Ghate, 1994). Similarly, Ramanella variegata 
Table 1. Checklist of amphibia of Maharashtra (compiled data).

Gymnophiona (Limb-less amphibia)

Icthyophiidae

1) Ichthyophis subterrestris Taylor

Caecilidae

2) Indotyphlus battersbyi Taylor *

Anura (Frogs and Toads)

Bufonidae

3) Bufo beddomii Günther

4) Bufo koynayensis Soman *

5) Bufo melanostictus Schneider *

6) Bufo microtympanum Boulenger

7) Bufo stomaticus Lutken *

8) Bufo parietalis Boulenger

Microhylidae

9) Microhyla ornata (Duméril and Bibron) *

10) Microhyla rubra Jerdon

11) Ramanella montana (Jerdon) *

12) Ramanella variegata (Stoliczka)

13) Uperodon globulosus (Günther) *

Ranidae

14) Indirana beddomeii [Rana beddomeii (Günther)] * Mulshi, Lonawla, Bhimashankar, Pune Dt.

15) Indirana leithii [Rana leithii Boulenger] * Simvagad, Mulshi Pune Dt., Matheran, Thane Dt.

16) Indirana phrynoderma [Rana phrynoderma Boulenger] ** Mulshi, Pune Dt.

17) Limnonectes keralensis [Rana keralensis Dubois] *

18) Limnonectes nilagirica [Rana nilagirica Jerdon] ** Mulshi, Pune Dt.

19) Limnonectes limnocharis [Rana limnocharis Gravenhorst] *

20) Limnonectes brevipalmata [Rana brevipalmata Peters]

21) Limnonectes syhadrensis [Rana syhadrensis Annandale] *

22) Hoplobatrachus tigerinus [Rana tigerina Daudin] *

23) Hoplobatrachus crassus [Rana crassa Jerdon] ?** Mulshi, Pune Dt.

24) Nyctibatrachus humayuni Bhaduri and Kripalani * Bhimashankar, Pune Dt. and Thoseghar, Satara Dt.

25) Nyctibatrachus major Boulenger ** Mulshi and Lonawala, Pune Dt.

26) Euphlyctis cyanophlyctis [Rana cyanophlyctis Schneider] *

27) Euphlyctis hexadactylus [Rana hexadactyla Lesson]

28) Rana malabarica Tschudi *

29) Rana aurantiaca Boulenger **

Thoseghar, Satara Dt.
30) Rana temporalis Günther *

Koyna, Mahabaleshwar, Satara Dt.

31) Rana curtipes Jerdon

32) Sphaerotheca breviceps [Tomopterna breviceps (Schneider)] * Pune City and Mulshi, Pune Dt.

33) Sphaerotheca rufescens [Tomopterna rufescens (Jerdon)] * Mulshi, Pune Dt.

34) Sphaerotheca dobsonii [Tomopterna dobsonii (Boulenger)] ** Mulshi, Lonawla, Pune Dt.

Rhacophoridae

35) Philautus bombayensis (Annandale)*

36) Philautus sp. (closer to bombayensis) ** Mulshi, Pune Dt.

37) Philautus glandulosus (Jerdon)

38) Philautus sp. (closer to glandulosus) ** Mulshi, Pune Dt.

39) Philautus leucorhinus (Lichtenstein and Martens) * Mulshi, Pune Dt.

40) Polypedates maculatus (Gray) *

41) Polypedates leucomystax (Gravenhorst)? @

42) Polypedates sp. (different from maculatus) **

Mulshi, Pune Dt.

43) Rhacophorus malabaricus Jerdon

? - Species identification yet to be confirmed.

* - Species we (our colleagues, friends and our team) have observed from different areas of Maharashtra State.

** - Species not present in Sekar's (1999) list, which are new locality records.

@ - Included as Rhacophorus leucomystax by Ravichandran and Pillai (1990). New names after Dutta, 1997; Das and Dutta, 1998; and Vences et al., 2000. Old names are given in square brackets beside the new names.

Table 2. Comparative status of family-wise distribution of amphibian species among 10 families in India, Western Ghats and Maharashtra State.

\begin{tabular}{llll}
\hline Family & India & Western Ghats & Maharashtra \\
\hline Salamandridae & 1 & 0 & 0 \\
Ichthyophiidae & 11 & 7 & 1 \\
Ureotyphlidae & 5 & 4 & 0 \\
Caecilidae & 5 & 3 & 1 \\
Pelobatidae & 10 & 0 & 0 \\
Bufonidae & 22 & 13 & 8 \\
Hylidae & 1 & 0 & 0 \\
Microhylidae & 18 & 12 & 5 \\
Rhacophoridae & 60 & 30 & 8 \\
Ranidae & 91 & 48 & 20 \\
Total & 224 & 117 & 43 \\
\hline
\end{tabular}


and $R$. montana are perhaps found only in a few forested areas. We collected R. montana from Mulshi area. Sekar (1991) pointed out that $R$. variegata is also found in Maharashtra, as per the records of Bombay Natural History Society's collection data. However, no recent sightings or reports are available on this species from the State. One of our students brought an injured specimen of Uperodon globulosus from Alibag. We found a small population of $U$. globulosus in Pune and breeding of this species is observed in very restricted localities. We have also collected tadpoles of $U$. globulosus from Pashan-Pune but could not locate the adults. However it is present in a farmhouse of one of our friends at Jambhe Village, near Pune City. Distribution and present status of Ramanella and Uperodon in Maharashtra however is absolutely uncertain and needs more extensive survey.

Ranidae members, with the exception of a few species, are distributed widely all over the Western Ghats. In spite of this, many are living precariously due to onslaught of deforestation, urbanization, pollution and concomitant habitat destruction. Hoplobatrachus tigerinus (Rana tigerina), once common around Pune, Satara, Kolhapur, whole of the Konkan area, etc., was hardly observed. However, conditions have certainly improved in the last 10 years since the ban on trade of froglegs and stopping the use of this frog for teaching purpose. This is evident from the calls of these frogs, which were heard from good many localities and the young ones seen around since about 1993. Euphlyctis cyanophlyctis (Rana cyanophlyctis) is still the commonest frog in Maharashtra (and perhaps elsewhere in the country). Indirana leithii (Rana leithii) is common in hill streams in places like Sinhagad, Rajgad, Matheran, and other hills, slightly away from crestline area of Western Ghats whereas I. beddomeii (Rana beddomii) is perhaps more common in the crestline areas. Limnonectes keralensis (Rana keralensis) is was only recently recorded from Maharashtra (Daniels, 1992b) and seems to inhabit crestline areas, but it is a common species down south. L. limnocharis (Rana limnocharis) and $L$. syhadrensis (Rana syhadrensis) seem to be more common in Maharashtra. Rana temporalis and R. malabarica are also still common species though they are more restricted in distribution in this State. R. temporalis lives and breed away from human habitation. It is more common in Konkan and restricted patches in crestline areas like Mahableshwar and Wasota (Koyna Reservoir). For the first time we have observed and collected specimens of $R$. aurantiaca from Thoseghar, a locality near Satara. There is also a recent report of $R$. curtipes from Amboli (Sekar 1999). R. malabarica is found in relatively undisturbed habitats in the hilly areas. It prefers paddy fields for breeding and is more common in western parts of Nasik, Pune, Satara and Kolhapur districts. It is also commonly found in Konkan area. One of our students has also collected a specimen from Tadoba, the eastern most part of the state.
Other Ranidae members like Sphaerotheca (=Tomopterna) are burrowing species and are seen only during monsoon, however these species are still common in peripheral urbanizing parts of Pune City and in rural areas around Pune City. It is common perhaps all over Maharashtra in suitable habitats like arid and semiarid lands. They usually breed in abandoned stone quarries and temporary rain pools along with Microhyla ornata. Of these, Sphaerotheca dobsonii (Tomopterna dobsonii) has been reported from Maharashtra (specimens studied from Panchagani and Khandala by Dutta, see Dutta 1997b). However, Sekar (1999) did not include it in the list of Maharashtra amphibians. Our $S$. dobsonii from Mulshi as well as Lonavla compares fairly well with the description given by Boulenger (1890), Pillai (1982) and Dutta (1986). The identity of the specimens was confirmed by Dr. S.K. Dutta.

Nyctibatrachus humayuni or the Wrinkled Frog is also common in forested crestline areas of the Western Ghats. The genus Nyctibatrachus, with only a few species, is endemic to the Western Ghats and as such deserves special attention from the conservation point of view. For the first time we have collected N. major from Tamhini in Mulshi Taluk, Pune District (identified by Dr. M.S. Ravichandran).

Family Rhacophoridae includes frogs that are more or less arboreal, hence presence of vegetation is essential for them. Philautus bombayensis was once a common frog in the shrubby vegetation nearby Pune City. Now this frog is available in much remote places where suitable vegetation is available. It is common in Sinhagad, Matheran, Bhimashankar, Mahableshwar and other places in the crestline areas. P. leucorhinus is however found in restricted patches and is also very rare. Same is true for $P$. glandulosus. We have so far seen species that is close to $P$. glandulosus only in Mulshi area of Pune District. Philautus is a difficult genus and appropriate keys are not available. Polypedates maculatus is very common both in Konkan as well as forested areas of rest of the state. We have observed this frog from different areas right from Tadoba and Mahoor - the eastern end of the state to Harihareshwar and Hedvi - the western end of the state.

We have recently observed a few specimens from Mulshi area in Pune District, which are distinctly different from Polypedates maculatus in having longer tibia and broader head. This unidentified species is not as common as that of the P. maculatus; found very rarely and only in some pockets. These variants are forwarded to the experts for comments.

Habitat destruction and its effects on amphibians of Pune have been discussed earlier (Ghate \& Padhye, 1996). The situation is more or less same for all major townships and cities in the state where urbanization and industrialization are the major threats to amphibian populations, but hard data is wanting. This has 
created a problem regarding the conservation of amphibia (Daniels, 1991).

Moreover, introduction of exotic fishes like Gambusia and Tilapia (Oreochromis) in waterbodies, which serve as amphibian breeding sites, has also wiped out amphibian populations. We have highlighted this issue earlier (Ghate \& Padhye, 1996). Knowing the voracious feeding habits of Tilapia, it is definitely going to affect the amphibian breeding in future. Tyler (as cited by Duellman \& Trueb, 1986) has already remarked that Gambusia and Tilapia are a threat to Australian frogs.

Speaking of data, we had very scanty quantitative estimates. However, the first international conference of IUCN (SSC), ISRAG at Bhubaneswar, Orissa, in 1992, and the Conservation Assessment and Management Plan (CAMP) workshop in 1997 motivated and oriented many amphibian workers in this direction. Consequently, some data was collected in last few years. Molur and Walker (1998) have given a broad overview of the status of amphibia in India and also the status of their research, conservation and management scenario. However, we still have hardly any significant quantitative data with respect to population size, reproductive potential, survival rates of tadpoles and metamorphosing frogs/toads etc., for the various species of amphibia in our country. In the absence of such data it will be impossible to note the changes in their populations. It may also be pointed out here that the natural history of several species is still not fully known.

In addition there is an urgent need for keys (with as many diagrams and photographs as possible) of amphibians. Fortunately, some notable efforts are being made for the frogs of Western Ghats since the time of Daniel $(1963,1975)$, Daniel and Sekar (1989) and recently by Daniels (1997a,b,c). Similar efforts are also taken by Chanda (1994) for amphibians of northeastern India. Also a key to Gymnophiona of India is provided recently by Pillai and Ravichandran (1999). However, with addition of some new species as well as revision of a few older ones, it becomes necessary to have a recent effort to accommodate all the Indian amphibian species. Therefore intense efforts are necessary to provide naturalists with up-todate keys. Checklists alone do not serve this purpose. Due to lack of such keys, newcomers to the field are frustrated. If we want to lure more students to taxonomy and systematics as a whole then we must prepare good illustrated keys to our valid species.

Even for widely distributed species, microhabitat requirements are quite specific and slight modification can be detrimental. We do not know much about temperature, humidity and rainfall requirement of many of our species. An attempt in this direction has been made by Daniels (1992a). On the basis of his own observations on 35 species as well as some previous records, he had presented patterns of geographical distribution and endemism of 117 Western Ghats amphibians. However, the data are from observations for only one year. Much more information is needed and unless such meaningful data incorporating all the ecological information of different species are collected, our efforts to conserve amphibia will be directionless, futile and hence wasted. Financial assistance and trained manpower is not available for extensive surveys of the entire state. If such surveys are not carried out in near future then we may never know the status of amphibians in Maharashtra State because there is considerable amount of habitat destruction all over Maharashtra.

We have recently conducted fresh surveys in an attempt to find out the status of amphibians in and around Pune City as well as in Pune District, on the background of such a large scale habitat destruction. The outcome of these surveys is presented separately (Padhye et al., in press).

\section{Acknowledgements}

We are thankful to our enthusiastic naturalist friends - Ashok Captain, Krushnamegh Kunte, Sanjay Thakur and Vivek GourBroome for bringing frog specimens and photographs from different areas of the State. This helped us in updating the list. We are also thankful to our students Rahul Marathe, Rahul Bahulikar, Sagar Pandit, Mukul Mahabaleswarkar, Nilesh Dahanukar, Rupesh Raut, Mandar Paingankar and Sachin Ranade. These enthusiastic students of UG and PG classes have helped us a lot in the actual survey and field work. We are thankful to Drs. S.K. Dutta (Utkal University, Bhubaneswar), S.K. Chanda (ZSI, Calcutta) and M.S. Ravichandran, (SRS, ZSI, Chennai), for their valuable help in identification of some of the specimens sent to them.

H.V.G. is thankful to the Principal, Modern College, and A.D.P. is thankful to the Head of the Zoology Department and Principal, Abasaheb Garware College for provision of infrastructural facilities for this work. Part of this work was done as a part of Western Ghats Biodiversity Monitoring Project, which was funded by Department of Biotechnology (DBT), for which we are thankful to the concerned authorities. Lastly, we are thankful to Dr. Madhav Gadgil for his valuable encouragement.

\section{References}

Bhat, G.K. (1997). Caecilian diversity of Western Ghats: In search of rare animals. Current Science 73(2): 183-187.

Boulenger, G.A. (1890). Fauna of British India including Ceylon and Burma, Reptilia and Batrachia. Taylor and Francis, London.

Chanda, S.K. (1994). Anuran (Amphibia) fauna of Northeast India. Memoirs of Zoological Survey of India 18(2): 1-143.

Daniel, J.C. (1963). Field guide to the amphibians of western India. Parts 1 \& 2. Journal of the Bombay Natural History Society 60: 415438; 690-702. 
Daniel, J.C. (1974). Amphibia. In: Kunte, B.G., Editor. Gazetteer of India, Maharashtra - State Gazetteers, General Series: Fauna. Government of Maharashtra Publication.

Daniel, J.C. (1975). Field guide to the amphibians of western India. Part 3. Journal of the Bombay Natural History Society 72: 506-522.

Daniel, J.C. and A.G. Sekar (1989). Field guide to the amphibians of western India, Part 4. Journal of the Bombay Natural History Society 86: 194-203.

Daniels, R.J.R. (1991). The problem of conserving amphibians in the Western Ghats, India. Current Science 60(11): 630-632.

Daniels, R.J.R. (1992a). Geographical distribution patterns of amphibians in the Western Ghats, India. Journal of Biogeography 19: 521-529.

Daniels, R.J.R. (1992b). Geographical range and ecology of the Verrucose Frog Rana keralensis (Dubois). Journal of the Bombay Natural History Society 89: 199-203.

Daniels, R.J.R. (1997a). A field-guide to amphibians of Western Ghats, India, Part I. Cobra 27: 1-25.

Daniels, R.J.R. (1997b). A field-guide to amphibians of Western Ghats, India, Part II. Cobra 28: 1-24.

Daniels, R.J.R. (1997c). A field-guide to amphibians of Western Ghats, India, Part III. Cobra 29: 1-13.

Das, I. and S.K. Dutta (1998). Checklist of the amphibians of India with English common names. Hamadryad 23: 63-68.

Dubois, A. and A. Ohler (1999). Asian and Oriental toads of the Bufo melanostictus, Bufo scaber and Bufo stejnegeri groups (Amphibia, Anura): a list of available and valid names and redescription of some name-bearing types. Journal of South Asian Natural History 4(2): 133180.

Duellman, W.E. and L. Trueb (1986). Biology of Amphibians. Mc Graw Hill Book Company, New York.

Dutta, S.K. (1986). Comments on the species, status and distribution of Tomopterna dobsonii Boulenger (Anura: Ranidae) in India. Records of the Zoological Survey of India 83 (1\&2): 123-127.

Dutta, S.K. (1992). Amphibians of India: Updated species list with distribution record. Hamadryad 17: 1-13.

Dutta, S.K. (1997). Amphibians of India and Sri Lanka (Checklist and Bibliography). Odyssey Publishing House, Bhubaneswar, 234+xxii pp. Ghate, H.V. and A.D. Padhye (1996). Impact of urbanization on amphibians of Pune. Zoos' Print 11: 14-16.
Inger, R.F. (1996). Commentary on a proposed classification of the family Ranidae. Herpetologica 52 (2): 241-246.

Inger, R.F. and S.K. Dutta (1986). An overview of the amphibian fauna of India. Journal of the Bombay Natural History Society (Supplement) 83: 135-146.

Kamble, S.S. and H.V. Ghate (1994). First record of Microhyla rubra (Jerdon), (Amphibia: Anura) from Maharashtra. Journal of the Bombay Natural History Society 91: 150-151.

Mani M. S. (1974). Ecology and Biogeography of India. Dr. W. Junk, B.V. Publishers, The Hague, The Netherlands.

Myers N., R.A. Mittermeier, C.G. Mittermeier, G.A.B. da Fonseca and J. Kent (2000). Biodiversity hotspots for conservation priorities. Nature 403: 853-858.

Molur, S. and S. Walker (1998). Conservation assessment of the herpetofauna of India - an overview. Hamadryad 23(2): 169-178.

Padhye, A.D., M. Mahabaleshwarkar and H.V. Ghate (In press). An overview of amphibian fauna of Pune District with special reference to amphibian decline in and around Pune City. Zoos' Print Journal (2002) 17(4).

Pillai, R.S. (1982). Notes on Rana dobsonii Boulenger. Records of the Zoological Survey of India 79: 363-365.

Ravichandran, M.S. and R.S. Pillai (1990). Amphibia of Maharashtra with description of a new species of Torrent Toad, Ansonia. Records of the Zoological Survey of India 86: 505-513.

Ravichandran, M.S. and R.S. Pillai (1999). Fauna of Gymnophiona of India. Records of the Zoological Survey of India, Occasional Paper No. 172. Zoological Survey of India, Calcutta.

Sekar, A.G. (1991). Distribution of amphibian fauna of India. Journal of the Bombay Natural History Society 88: 125-127.

Sekar, A.G. (1999). Four new records and checklist of amphibians from Maharashtra. Journal of the Bombay Natural History Society 96(1): 152-157.

Vences, M., F. Glaw, J. Kosuch, I. Das and M. Veith (2000). Polyphyly of Tomopterna (Amphibia: Ranidae) based on sequences of the Mitochondrial $16 \mathrm{~S}$ and $12 \mathrm{~S}$ rRNA genes, and ecological biogeography of Malagasy relict amphibian groups, pp. 229-242. In: Diversite et Endemisme a Madagascar.

Yazdani, G.M. and A. Mahabal (1976). Amphibians of Poona. Newsletter of the Zoological Survey of India 2: 138-139. 